\title{
The Impact of Government Expenditure on the Greek Government Debt: An Econometric Analysis
}

\author{
Gisele Mah ${ }^{1}$ \\ Janine Mukkudem-Petersen² \\ Collins Miruka ${ }^{3}$ \\ Mark A. Petersen 4 \\ North-West University, South Africa. \\ ${ }^{1}$ Gisele.Mah@nwu.ac.za \\ 2Janine.Mukuddem.Petersen@nwu.ac.za \\ ${ }^{3}$ collins.miruka@nwu.ac.za \\ 4Mark.Petersen@nwu.ac.za
}

\section{Doi:10.5901/mjss.2013.v4n3p323}

\begin{abstract}
Sovereign debt crisis in advanced economies keep increasing and its government are implementing fiscal policies to reduce it. Greece is an example of a country whose government debt is a matter of grave concern since it has received the second bailout but still threatens to default. The main aim of this study is determine the impact of government expenditures and government incomes on government debt. This paper estimates the effect of government expenditure on debt in Greece via the vector error correction model framework and granger causality model with annual data from 1976 to 2011 which was collected from the World Development Indicators, European Commission data base and the International Monetary Fund. Vector Error correction Model framework is used to estimate our model and Vector Autoregression Granger causality to determine the direction of causation. The results show a significant negative relationship between gross government debt and gross national income as well as gross government debt and net foreign direct investment. A significant positive relationship is found between gross government debt and gross national expenditure and gross government debt and inflation. The past values of gross national expenditure and gross national income have a predictive ability in determining the present value of gross government debt and not vice versa. Knowing this effects will help policy makers of these countries and the world at larger to revisit its fiscal policy in order to reduce its debt and sustain it.
\end{abstract}

Keywords: Greece; Government Debt; Gross National Expenditure; Vector Error Correction Model; Granger causality.

\section{Introduction}

Sovereign debt crisis in advanced economies keep increasing. In particular, developed economies are cutting down spending and increasing taxes with the aim of reducing sovereign debt or preventing the country from experiencing debt crisis. Greece had a sovereign debt rate as a percentage of GDP that has been increasing from $112.9 \%$ in 2008 and $161.6 \%$ in 2012 according to statistics from European commission data base (AMECO). According to Burdan and Wyplosz (2010), there are three ways which the government can stabilise the increasing debt-GDP which are: fiscal contraction, inflationary finance and default on some or all the existing debt. According to Follette and Lutz (2010), fiscal policy tools was use to address the aggregate demand of the crisis in most developing countries.

Some studies were conducted such as that done by IMF (2010) which examines the effects of fiscal consolidation on economic activities. The results show that fiscal consolidation reduces output, increases interest rates, increases export rates and raises unemployment in the short term. Blanchard and Perotti (2002) did a study on the dynamic effects of shocks in government spending and taxes on economic activity in the US during the post war period. The result shows that when government spending increases, output increases and when taxes increases, output falls. Spending shocks makes private consumption to increase while private investment crowds out export and import both reduces. A positive government spending shocks has a positive effect on output and positive tax shocks as having a negative effects. Increase in taxes and government spending have a strong negative effects on private investment. Romer and Romer (2010) investigated the impact of changes in the level of taxation on economic activities in the US using the narrative record. The results show that changes in tax level in US are as a result of increase in government spending which addresses inherited budget deficit and promotes long run growth. The consequences are that: there is a large effect on output. Sinhal et al. (2011) studied the determinant of public debt for the middle income and high income group countries 
using panel data regression. The result show that the central government expenditures, education expenditures and current account balance affect the debt rates of both middle and high income countries.

Some studies have investigated the cause of the sovereign debt crisis to varying degrees and with different approaches (Hsing, 2010; Pattillo et al., 2002; Checherita and Rother, 2010; Scheclrek, 2004; Budina et al., 2005; Akam et al. 2011; Arghyrou and Tsoukalas, 2010; Nelson et al., 2011; Kouretas and Vlamis, 2010; Whelan, 2011). Contrary to these studies we will investigate the effect of the Greek expenditure and income on its government debt. In this regard, we will employ the VECM to determine the short and long run relationship between our dependent and independent variables. Also, the Granger causality test is used to determine the direction of causality among our variables. These results provide significant information on how to achieve sustainable debt levels to role-players, economists and policy makers alike in Greece.

The remainder of this paper is structured as follows. The current section is of an introductory nature and background for section 2. Section 3 reviews the theoretical framework and the empirical literature related to Government expenditure and debt. Section 4 presents and motivates the choice of the VECM and the Granger causality technique. Section 5 will discuss the results while Section 6, conclusions are drawn and policy suggestions are made from the research findings.

\section{Background of austerity measures in the Greece economy}

According to the World fact book (2013), the economy of Greece was growing fast during the 2003 to 2007 with a growth rate of $4.0 \%$ per annum. In 2008, the Financial Crisis affected the Greece economy with its tourism and shipping industries being greatly affected.

This government started deficit-cutting policy in 2010 by lowering their spending through reduction in the amount of benefits and public services provided. The government increased taxes at the same time, a number of austerity packages adopted, Heninz (2011).

Greece's first austerity measures took place in February 2010 where the International Monetary Fund (IMF) and European Central Bank (ECB) signed a memorandum. The package consisted of the following: $10 \%$ cut in bonuses and overtime, public employees and work related travels. This austerity measure package did not meet the objectives in the bailout package to established Greek access to private capital markets in 2012. By the end of March 2010, the Greek government could no longer refinance its maturing debts or raise new capital. Due to fear of bankruptcy, the Greek parliament passed the economic protection bill which was expected to save another €4.8 billion. The second austerity measure included a 30\% cut in Christmas, Easter and leave bonuses, an additional $12 \%$ cut in public bonuses, $7 \%$ cut in salaries of public and private employees, increase in Value Added Tax (VAT) from the range of $4 \%$ to $5 \%$, a rise in petrol tax from $9-10 \%$ to $15 \%$ and an increase in imported cars from $10 \%$ to $30 \%$. It later on created a tripartite committee (the Troika) which comprise European Commission, IMF and ECB.

A third austerity measure was announced at the beginning of May, 2010 by Prime Minister George Papandreou. This was to save $€ 38$ billion through 2012. This third package included an additional 8\% cut in public sector allowances, $3 \%$ cut in public sector utilities of employees, $10 \%$ increase imported cars, increased in values added taxes from $19 \%$ to $23 \%, 10 \%$ increase in luxury, alcohol, cigarettes and fuel, increase in retirement age from 61 to 65 , reduction in public owned companies from 6000 to 2000 and reduction in number of municipalities from 1000 to 400 . These austerity measures were observed but still Greece could not improve its public finance.

In April 23th 2010, Greece realised that the austerity measure could not improve the economic position, so they requested for a bailout package from EU/IMF to be activated. The IMF contributed €30 billion while other Eurozone partners added $€ 80$ billion. Anand et al. (2012) and Calice et al. (2011) confirmed that on the $2^{\text {nd }}$ of May 2010, a bailout package of $€ 110$ billion was given to Greece which will be followed by implementation of the austerity measures on the 9 May 2010. Alogoskoufis (2012) concurs and added that alongside the first bailout package, the European Financial Stability Facility (EFSF) was created to issue bonds and other debts instruments in the markets.

The fourth austerity measure was implemented in June 2011 whereby privatisation and sales of government properties was increased by $€ 50$ billion, taxes were increased for those earning over $€ 8,000$ billion per year and an extra tax for those with a yearly income of $€ 12,000$. Increase in VAT in the housing industry, lowering the pension payments from $6 \%$ to $14 \%$ to the previous $4 \%$ to $10 \%$ and many other taxes. It was finally agreed that $50 \%$ of the debt should be written off as a condition to extend more aid by the troika. In October 2011, private investors agreed to take a $50 \%$ cut on the face value of bonds and not the 21\% that was agreed upon in July 2011.

In February 2012, the Greek cabinet approved a draft bill of the fifth austerity measure which was to improve the 
2012 budget deficit with $€ 3.3$ billion. It included a $22 \%$ cut in the minimum wage from the $€ 750$ per month. There will be no more holidays bonuses, 150000 jobs will be reduced; pension will be decreased by $€ 300$ in 2012. Spending on health, defence will decrease while privatisation will increase to $€ 15$ billion by 2015.

According Castel (2012), Greece was granted a second rescue package of $€ 130$ billion in March 2012. The package was authorized to be released in installments with the first being $€ 39.4$ billion of loans from the EFSF.

\section{Literature review}

This section focuses on both theoretical and empirical literature. We did adopt the Keynesian theory which is the relationship between our variables. Empirical literature focuses on the determinants of government debt.

Keynesian economists were of the opinion that the government can control aggregate demand and the level of national income through spending and tax policies. Since current government budget balance is the difference between its spending and receipts. That is, $B_{t}=G_{t}-T_{t}$ where $\mathrm{Bt}$ is the balance at time $\mathrm{t}, \mathrm{G}_{\mathrm{t}}$ and $\mathrm{T}_{\mathrm{t}}$ are the levels of government spending and tax revenues at time t respectively. Government debt is derived as $D_{t}=(1+r) D_{t-1}+B_{t}$, he national debt evolves as $D_{t}=(1+r) D_{t-1}+G_{t}-T_{t}$. Government debt is the accumulated total of all its deficits and surplus budget and the associated interest payment involved in serving the debt.

Empirically, Hsing (2010), Pattillo et al. (2002), Checherita and Rother (2010), Yue (2010), Schecherk (2004), Dimitriosi et al. (2011) conducted studies on the determinants of government debt, we will analyse just two. Budina et al. (2005) studied the determinants of public debt in 15 market access countries. The determinants of public debts to GDP ratios where fiscal deficit as a share of GDP, real GDP growth, real interest rates, real exchange rates and inflation. The method used was public debt decomposition. The framework analyses the public debt trend between 1990 and 2002 by decomposing past changes in public debt-to-GDP ratios into a number of explanatory factors. The results show that public sector debt decreases due to increase in real GDP growth, real exchange rate appreciation, fiscal surplus, reduction in real interest rate. Our study will use inflation as independent variables and add gross government expenditure, gross government income and net foreign direct investment. Our methodology differs from the public debt decomposition used in this study, since we used the VECM to find out variables that influence government debt in Greece.

Sinha et al. (2011) conducted a study of the determinants of public debt for middle and high income group countries using panel data regression. The data was from 1993 to 2008 for high income group countries and 1980 to 2008 for middle income group countries. They estimated a model using the Indian market, where their dependent variable was public debt to GDP of the country and their independent variables were: current account balance, central government expenditure, long term interest rate, and real GDP growth rate, inflation at consumer price, FDI and population density. The result shows that: central government expenditure, long term interest rate, and real GDP growth rate, inflation at consumer price, and FDI are significant while current account balance and population density was insignificant. They added autoregressive terms of the variables, the results shows that inflation, interest rate, population density, FDI and expenditure are insignificant while current account and GDP growth are the only two variables that significantly affect total debt of the middle income group countries when using the auto regressive model. Their total debt is negatively related to GDP growth while current account is positively related to total public debt. For the high income group countries, the auto regressive model shows that the total debt depends on the GDP growth rate while other variables are insignificant. Our variables will be government debt, gross government expenditure, gross government income, inflation and net FDI. We will adopt the model of this study.

\section{Data and Methodology}

\subsection{Data}

Annual data from the period 1976 to 2011 were collected from various sources. Greek general government debt (GDEBT) was obtained from the European commission data base. Gross national expenditure (GNEXP), gross national income (GNINC) and net foreign direct investments (NFDI) was sourced from World Development Indicators (WDI). Inflation (INF) data came from WDI and the IMF. GDEBT is in percentage of GDP because we could not get it in figures. INF is in annual percentage, GNEXP, GNINC and NFDI are in billions of the constant local currency. 
From our literature review, we adopt a similar model to that of Sinha et al (2011) which is adjusted to fit the Greek situation. In this context a regression analysis is done primarily to analyse the relationship between the dependent and independent variables. The independent variables are: GNEXP, GNINC, INF and NFDI while the dependent variable is GDEBT. The relationship between the dependent and the independent variables are proposed in the functional relationship of the form:

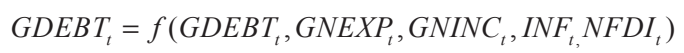

Where GDEBT is the general government debt, GNEXP is the gross national expenditure, GNINC is the gross national income, and NFDI is the net foreign direct investments. The variables are transformed into logarithms to help with the interpretation of the estimated coefficients as elasticities and also with the problem of different units of measurements of the various variables. It makes non-linear parameters in a model linear, Asteriou and Hall (2007). The regression equation expressed in natural logarithms is as follows:

$$
\operatorname{In}\left(G D E B T_{t}\right)=\beta_{o}+\beta_{1} \operatorname{In}\left(G N E X P_{t}\right)+\beta_{2} \operatorname{In}\left(G N I N C_{t}\right)+\beta_{3} \operatorname{In}\left(L I N F_{t}\right)+\beta_{4} \operatorname{In}\left(N F D I_{t}\right)+\varepsilon_{t}
$$

\subsection{Methodology}

The VECM is used which include various tests such as the Phillips and Perron (PP) and Augmented Dickey Fuller (ADF) tests. If the variables are found to be non stationary at levels, we proceed to test at first difference and so on when deciding whether to reject the null hypothesis of the unit roots or not. The PP test is considered here because it accounts for possible correlation in the first differences of the time-series using a nonparametric correction, and allows for the presence of a non-zero mean and a deterministic time trend (Enders, 2010).

When the existence of a unit root is confirmed for a data series, the question is whether there exists some long-run equilibrium relationship among the variables. The existence of a long-run equilibrium relationship among economic variables is called cointegration. Before conducting a cointegration test, the suitable lag length is estimated to see which number of lags best fits the time series data. The estimation of the appropriate lag length is based on different information criteria for the selection of a model such as: Akaike information criterion (AIC), Schwarz information criterion (SC) and Hannan-Quinn information criterion (HQ). Liew (2004) mentioned that when observations are less that sixty, the AIC results are superior than the SIC and $\mathrm{HQ}$ criterion when determining to get a good lag length.

The Johansen technique is used for cointegration. According to Chang et al. (2011), the Johansen technique permits us to have more than one cointegrating relationship since there could be one that one conintegration relationship among variables. Johansen proposes two different likelihood ratio tests, namely the trace test and the maximum Eigen value test. These tests take the following form:

$$
\begin{aligned}
& J_{\text {trace }}=-T \sum_{i=r+1}^{n} \operatorname{In}\left(1-\bar{\lambda}_{i}\right) \\
& J_{\max \text { Eigen }}=-\operatorname{TIn}\left(1-\bar{\lambda}_{r+1}\right)
\end{aligned}
$$

Where $T$ is the sample size and $\bar{\lambda}$ is the $i^{\text {th }}$ largest canonical correlation.

The VECM specify both the long run and short run relationships whereby the long run components of our variables are to obey equilibrium constraints and the short-run components have a flexible dynamic specification. The idea is simply that a proportion of the disequilibrium from one period is corrected in the next period. It involves estimating the model in the first difference form and adding an error correction term as an explanatory variable as follows:

$$
\Delta I n\left(G D E B T_{t}=\beta_{0}+\sum_{i=n-1}^{n} \beta_{1} \Delta I n\left(G N E X P_{t-1}\right)+\sum^{n} \beta_{2} \Delta n\left(G N I N C_{t-i}\right)+\sum_{i=n-1}^{n} \beta_{3} \Delta n\left(I N F_{t-1}\right)+\sum_{i=n-1}^{n} \beta_{4} \Delta I n\left(N F D I_{t-1}\right)+\beta_{5} E C T_{t-1}+\chi\right.
$$

If the coefficient of Error Correction Term (ECT) is negative and statistically significant, it tells us what proportion of the disequilibrium in GDEBT is corrected in the next period. After estimating our VECM, we test if our model is good by conducting stability and diagnostic tests.

The next technique is the VAR granger causality which informs us of the causal link between government debt and its independent variables. According to Gujarati and Porter (2009), the existence of a relationship between variables does not mean causation and also does not prove the direction of causation. The bivariate regression of the granger causality test is estimated as:

$$
L G D E B T_{t}=\sum_{i=1}^{n} \alpha_{1 i} L G D E B T_{t-1}+\sum_{j-1}^{n} \alpha_{2 i} L G N E X P_{t-j}+v_{t}
$$




$$
L G N E X P_{t}=\sum_{i=1}^{k} \beta_{1 i} L G D E B T_{t-1}+\sum_{j=1}^{k} \beta_{2 i} L G N E X P_{t-j}+\mu_{t}
$$

The formula above in equations 6 and 7 is for LGDEBT and LGNEXP. This is done for LGDEBT and the other independent variables by extending the bilateral causality through the technique of VAR.

\section{Results and discussion}

The reliability of our data is based on the probability value; we choose $10 \%$ to determine our level of significance. As shown in Table 1 below, the null hypothesis of no unit roots for all our time series is accepted at level form since the ADF and PP test statistics values are higher than the critical values at $1 \%$ level of significance. In other words, our variables are non stationary at level form. LGDEBT, LINF and LNFDI are stationary at first difference while LGNEXP and LGNINC are stationary at second difference.

Table 1: Unit root test of time series with ADF and PP tests at intercept

\begin{tabular}{|c|c|c|c|c|c|c|c|}
\hline & \multicolumn{3}{|c|}{ ADF Test } & \multicolumn{4}{c|}{ PP Test } \\
\hline Variables & $\begin{array}{c}\text { t-values } \\
\text { (lags) }\end{array}$ & $\begin{array}{c}\text { Probability } \\
\text { value }\end{array}$ & SIC & $\begin{array}{c}\text { t-values } \\
\text { (Bandwidth) }\end{array}$ & $\begin{array}{c}\text { Probability } \\
\text { value }\end{array}$ & SIC & $\begin{array}{c}\text { Order of } \\
\text { integration }\end{array}$ \\
\hline LGDEBT & $-4.807^{\star \star \star}$ & 0.001 & -2.102 & $-5.009^{\star \star \star}$ & 0.000 & -2.102 & $\mathrm{I}(1)$ \\
\hline LGNEXP & $-6.019^{\star \star \star}$ & 0.000 & -4.041 & $-6.0193^{\star \star \star}$ & 0.000 & -4.041 & $\mathrm{I}(2)$ \\
\hline LGNINC & -1.991 & 0.289 & -4.561 & $-6.496^{\star \star}$ & 0.000 & -4.527 & $\mathrm{I}(2)$ \\
\hline LINF & $-9.428^{\star \star \star}$ & 0.000 & 0.881 & $-9.428^{\star \star \star}$ & 0.000 & 0.881 & $\mathrm{I}(1)$ \\
\hline LNFDI & $-2.689^{\star}$ & 0.089 & 8.206 & $-20.637^{\star \star \star}$ & 0.000 & 8.560 & $\mathrm{I}(1)$ \\
\hline
\end{tabular}

Note: Reject at $10 \%\left(^{*}\right), 5 \%\left(^{* *}\right), 1 \%\left(^{* *}\right)$ significance level

The result from Table 2 below shows that the lag length of two is best for our variables as shown by the asterisk on the various criteria.

Table 2. Selection of the lag length used in the study at level form

\begin{tabular}{|c|c|c|c|c|c|c|}
\hline Lag & LogL & LR & FPE & AIC & SC & HQ \\
\hline 0 & -56.118 & NA & $2.51 \mathrm{e}-05$ & 3.595 & 3.820 & 3.672 \\
\hline 1 & 98.685 & 254.969 & $1.23 \mathrm{e}-08$ & -4.040 & -2.693 & -3.581 \\
\hline 2 & 150.442 & $70.025^{\star}$ & $2.83 \mathrm{e}-09^{*}$ & $-5.614^{\star}$ & $-3.145^{\star}$ & $-4.772^{*}$ \\
\hline
\end{tabular}

The Johansen cointegration result (see Table 3) shows that there are two cointegrating equations with the trace test and one with the Maximum Eigen value test. Since the Maximum Eigen value test is more accurate than the Trace test, we conclude that there is one cointegrating long run equation for Greece.

Table 3. Cointegration results with trace and maximum Eigen value tests

\begin{tabular}{|c|c|c|c|c|c|c|c|}
\hline $\begin{array}{c}\text { Hypothesized } \\
\text { No. of CE(s) }\end{array}$ & $\begin{array}{c}\text { Eigen } \\
\text { Value }\end{array}$ & $\begin{array}{c}\text { Trace } \\
\text { Statistic }\end{array}$ & $\begin{array}{c}\mathbf{0 . 0 5} \text { Critical } \\
\text { Value }\end{array}$ & Probability & $\begin{array}{c}\text { Max-Eigen } \\
\text { Statistics }\end{array}$ & $\begin{array}{c}\mathbf{0 . 0 5} \text { Critical } \\
\text { Value }\end{array}$ & Probability \\
\hline None $^{*}$ & 0.908 & 130.172 & 69.818 & 0.000 & 78.622 & 33.877 & 0.000 \\
\hline At most 1 & 0.513 & 51.551 & 47.856 & 0.022 & 23.701 & 27.584 & 0.145 \\
\hline At most 2 & 0.371 & 27.850 & 29.797 & 0.083 & 15.295 & 21.132 & 0.269 \\
\hline At most 3 & 0.235 & 12.555 & 15.495 & 0.132 & 8.855 & 14.265 & 0.298 \\
\hline At most 4 & 0.106 & 3.700 & 3.841 & 0.054 & 3.700 & 3.841 & 0.054 \\
\hline
\end{tabular}

Our VECM presents results of both the long run (Table 4) and short run equation (Table 5) of our variables. From the Table 4, all the coefficient are on one side from the Eviews results, as such, we have to keep LGDEBT on one side and send all the other variables on the other side. The long run equation for Greece is

LGDEBT=40.58 + 16.82LGNEXP -15.22LGNINC +1.49 LINF - 0.04 LNFDI - 0.12e. 
The results indicate that all our variables are significant. A 1\% increase in LGNEXP will cause LDEBT to increase by $16.82 \%$. A $1 \%$ increase in LGNINC will cause LGDEBT to decrease by 15.22 . A $1 \%$ increase in INF will cause LGDEBT to increase by $1.49 \%$ while a $1 \%$ increase in LNFDI will cause LGDEBT to decrease by $0.04 \%$. All the signs of our variables coincide with economic theory. For instance, the error correction term is -0.12 . It is negative and significant as anticipated by theory. This implies that equilibrium will be adjusted at $88 \%$ speed of adjustment from the previous year's disequilibrium hence suggesting the speed of convergence to equilibrium if there appears a shock in the country.

Table 4. Long run coefficient and level of significance

\begin{tabular}{|c|c|c|c|c|c|c|}
\hline Variables & LGDEBT & LGNEXP & LGNINC & LINF & LNFDI & Constant \\
\hline Coefficient & 1.000 & -16.815 & 15.221 & -1.492 & 0.0360 & 40.583 \\
\hline t-statistics & & -9.176 & 6.915 & -13.691 & 4.777 & \\
\hline
\end{tabular}

Our $\mathrm{R}$ square is $67.44 \%$, indicating that a change in LGDEBT is explained by $67.44 \%$ of our independent variables in the long run. In the short run, at a lag of 2, LGNEXP, LINF are significant in determining LGDEBT while LINF and LNFDI are insignificant.

Table 5. Error correction term and level of significance

\begin{tabular}{|c|c|}
\hline Variables & D(LGDEBT) \\
\hline Error correction term & -0.122 \\
\hline T statistics & -3.876 \\
\hline
\end{tabular}

The error correction term for our variable is -0.122 which has a the correct signs and is statistical significant.

Table 5. Short run error correction results

\begin{tabular}{|c|c|c|}
\hline Variables & Coefficient & T statistics \\
\hline CointEq1 & & \\
\hline $\mathrm{D}($ LGDEBT(-1)) & -0.279 & -1.848 \\
\hline $\mathrm{D}($ LGDEBT(-2)) & -0.241 & -1.641 \\
\hline $\mathrm{D}($ LGNEXP(-1)) & -2.706 & -2.498 \\
\hline $\mathrm{D}($ LGNEXP $(-2))$ & 0.184 & 0.210 \\
\hline $\mathrm{D}($ LGNINC (-1)) & 1.365 & 1.011 \\
\hline $\mathrm{D}($ LGNINC (-2)) & 1.011 & -0.128 \\
\hline $\mathrm{D}($ LINF(-1)) & -0.211 & -3.055 \\
\hline $\mathrm{D}($ LINF(-2)) & -0.183 & -2.509 \\
\hline $\mathrm{D}($ LNFDI (-1)) & 0.002 & 2.003 \\
\hline $\mathrm{D}($ LNFDI (-2)) & -0.000 & -0.288 \\
\hline R-squared & 0.674 & \\
\hline Adj. R- squared & 0.504 & \\
\hline
\end{tabular}

After estimating our model as shown in the equation above, we then tested if the model was stable. Our result shows that our model is stable since the dots are found in the circle as shown in Appendix 1 below. Other diagnostic tests were conducted for serial correlation, heteroskedasticity and normality. The results in Appendix 2 below reveal that our model is stable, there is no serial correlation, no heteroskedasticity and the errors are is normally distributed.

The Granger causality test is conducted to determine whether the current and lagged values of one variable affect another. A simple Granger causality test involves two variables, viz., LGDEBT and LGDEF. We will further explain Granger causality among our variables.

The null hypothesis as stated in Table 7 below is not rejected when the probability value is greater than $10 \%$, since this is the preferred level of significance. If less than $10 \%$, then we reject the null hypothesis and accept the alternative for Granger causality. The results in Table 7 show that the past values of LGNEXP have a predictive ability in determining the present value of LGDEBT while the past value of LGDEBT does not have a predictive ability in determining LGNEXP. Hence, LGNEXP and LGNINC Granger cause LGDEBT and not vice versa. 
Table 7. The Granger Causality Tests results

\begin{tabular}{|c|c|c|c|c|}
\hline Null Hypothesis & $\begin{array}{c}\text { Number of } \\
\text { observation }\end{array}$ & F-statistics & Probability & Conclusion \\
\hline $\begin{array}{l}\text { LGNEXP does not Granger Cause LGDEBT } \\
\text { LGDEBT does not Granger Cause LGNEXP }\end{array}$ & 34 & $\begin{array}{l}6.64290 \\
1.08811\end{array}$ & $\begin{array}{l}0.0042 \\
0.3502\end{array}$ & $\begin{array}{l}\text { Causality } \\
\text { No causality }\end{array}$ \\
\hline $\begin{array}{l}\text { LGNINC does not Granger Cause LGDEBT } \\
\text { LGDEBT does not Granger Cause LGNINC }\end{array}$ & 34 & $\begin{array}{l}8.96291 \\
0.92573 \\
\end{array}$ & $\begin{array}{l}0.0009 \\
0.4076\end{array}$ & $\begin{array}{l}\text { Causality } \\
\text { No causality }\end{array}$ \\
\hline $\begin{array}{l}\text { LINF does not Granger Cause LGDEBT } \\
\text { LGDEBT does not Granger Cause LINF }\end{array}$ & 34 & $\begin{array}{l}0.02080 \\
4.00093\end{array}$ & $\begin{array}{l}0.9794 \\
0.0292\end{array}$ & $\begin{array}{l}\text { No causality } \\
\text { Causality }\end{array}$ \\
\hline $\begin{array}{l}\text { LNFDI does not Granger Cause LGDEBT } \\
\text { LGDEBT does not Granger Cause LNFDI }\end{array}$ & 34 & $\begin{array}{l}0.01228 \\
2.17780\end{array}$ & $\begin{array}{l}0.9878 \\
0.1315\end{array}$ & $\begin{array}{l}\text { No causality } \\
\text { No causality }\end{array}$ \\
\hline $\begin{array}{l}\text { LGNINC does not Granger Cause LGNEXP } \\
\text { LGNEXP does not Granger Cause LGNINC }\end{array}$ & 34 & $\begin{array}{l}0.13447 \\
1.00378 \\
\end{array}$ & $\begin{array}{l}0.8747 \\
0.3789\end{array}$ & No causality \\
\hline $\begin{array}{l}\text { LINF does not Granger Cause LGNEXP } \\
\text { LGNEXP does not Granger Cause LINF }\end{array}$ & 34 & $\begin{array}{l}2.99227 \\
1.58223\end{array}$ & $\begin{array}{l}0.0659 \\
0.2227\end{array}$ & $\begin{array}{l}\text { Causality } \\
\text { No causality }\end{array}$ \\
\hline $\begin{array}{l}\text { LNFDI does not Granger Cause LGNEXP } \\
\text { LGNEXP does not Granger Cause LNFDI }\end{array}$ & 34 & $\begin{array}{l}0.25723 \\
7.23927 \\
\end{array}$ & $\begin{array}{l}0.7749 \\
0.0028\end{array}$ & $\begin{array}{l}\text { No causality } \\
\text { Causality }\end{array}$ \\
\hline $\begin{array}{l}\text { LINF does not Granger Cause LGNINC } \\
\text { LGNINC does not Granger Cause LINF }\end{array}$ & 34 & $\begin{array}{l}2.47921 \\
1.00521 \\
\end{array}$ & $\begin{array}{l}0.1014 \\
0.3784\end{array}$ & $\begin{array}{l}\text { No causality } \\
\text { No causality }\end{array}$ \\
\hline $\begin{array}{l}\text { LNFDI does not Granger Cause LGNINC } \\
\text { LGNINC does not Granger Cause LNFDI }\end{array}$ & 34 & $\begin{array}{l}0.60970 \\
6.99881\end{array}$ & $\begin{array}{l}0.5503 \\
0.0033\end{array}$ & $\begin{array}{l}\text { No causality } \\
\text { Causality }\end{array}$ \\
\hline $\begin{array}{l}\text { LNFDI does not Granger Cause LINF } \\
\text { LINF does not Granger Cause LNFDI }\end{array}$ & 34 & $\begin{array}{l}2.50979 \\
13.3735 \\
\end{array}$ & $\begin{array}{l}0.0988 \\
8 . E-05 \\
\end{array}$ & $\begin{array}{l}\text { Causality } \\
\text { Causality }\end{array}$ \\
\hline
\end{tabular}

\section{Conclusion}

This paper analyses the impact of gross national government expenditure on general government debt in Greece thought the VECM and VAR granger causality approach. The VECM results show that gross national government expenditure, gross national income, inflation and net foreign direct investment significantly affect general government debt in Greece. There is a significant positive relationship between gross national government expenditure and inflation with general government debt meaning that and increase in gross national government expenditure and inflation will cause general government debt to increase. A negative significant relationship was found between gross national income and net foreign direct investment with general government debt, increase in and net foreign direct investment will cause general government debt to increase. Gross national government expenditure as compare the other variables has the greatest effect on general government debt. We recommend that policy be put in place to decrease expenditure as is done through the austerity measures until they are able to sustain their debt. Also, the Greek government should generate more income especially from its service sector which is the main engine in its economy. They should keep inflation high and encourage net foreign direct investment in its country. The only way of out debt crisis in Greece is a painful scarifies austerity.

The VAR granger causality results shows causality from gross national government expenditure and gross national income to general government debt. The implication of these results for the Greek government and policy makers is that since gross national government expenditure causes general government debt but general government debt does not affects gross national government expenditure, policies to be implemented should target gross national government expenditure first. This is because by targeting gross national government expenditure, it will affect general government debt. We recommend that policy maker should first target and gross national income which will affect. When general government debt is targeted first, it will affect inflation. The VECM and VAR granger causality results confirm that gross national government expenditure has a significant impact on general government debt.

\section{References}

Alogoskoufis, G. (2012) Greece's sovereign Debt Crisis: Retrospect and Prospect Hellenic observationary European Institute, papers on Greece and Southeast Europe, GreeSE, 54(2012).

Anand, M.R., Dash R. \& Gupta G.L. (2012) The Eurozone crisis: its dimensions and implications. Economic Division in the Department of Economic Affairs and Ministry of Finance of Indian. $22 \mathrm{p}$.

Asteriou, D. \& Hall G.S. (2007) Applied Econometrics. A modern Approach using Eviews and Microfit Revised Edition (Palgrave Macmillan). 
Babatunde, A. M. \& Adefabu A. R. (2005) Long run relationship between Education and Economic growth in Nigeria: Evidence from the Johansen's cointergration Approach, Paper presented at the Regional conference on Education in West Africa: Constraint and opportunities Dakar. Senegal. 1-2 Nov.

Black, P., Caltiz, E. \& Steennekamp (2012) Public Economics. 5th ed (Oxford: University Press Southern Africa Ltd).

Budina, N., Fiess, N. et al. ( 2005) Public sector debt and its determinants in market access countries. Results from 15 countries case studies. World Bank. March. http://siteresources.worldbank.org/INTDEBTDEPT/Resources/468980-1225740508953 /MACCaseStudiesMar05.pdf. Date of access: 27 April. 2012.

Calice, G., Chen, J. \& Williams, J. (2011) Liquidity spill over in sovereign bond and CDS markets: An analysis of the Euro Zone sovereign debt crisis. Journal of Economics Behaviour and Organisation.

Castle, S. (2012.) With details settled, a second Greek Bailout is Formally Approved. The New York Time. http://www.nytimes.com /2012/03/15/business/global/greece-gets-formal-approval-for-second-bailout.html?_r=1. Data access on: 20 March. 2012.

Chang, C., Fabiola, C. \& Carballo S. (2011) Energy conservation and sustainable economic growth: The case of Latin America and the Caribbean Energy policy, 39(2011):4215-4221.

Chawluk, A. (2000) Estimate of demand for money and consumption functions for the house hold sector in Poland, 1967- 1999. University of Oxford: department of Economics. Discussion paper, ( 42), ISSN 1471-0498.

Checherita, C., \& Rother, P. (2012) The impact of high and growing government debt on economic growth, An empirical investigation for area European Economic Review journal, 56(2012): 1392-1405.

Dimitriosi, K. et al. (2011). Determinant of national debt: Evidence from the Greek economy in the last decade. Journal of economic and research, 2(5):22-32.

Gujarati, D.N \& Porter. (2009). Basic Econometrics. 5th ed. McGraw Hill international edition.

Heinz, D. (2011) European debt crisis 2011. Portugal, Ireland, Italy, Greece, Spain and Belgium IAC Society, 138 p.

Hsing, Y. 2010. The Government Debt and the Long Term Interest Rate: Application of the Loanable Funds Model to Greece Journal of Economics Integration. 25(4): 722 to 733.Dec.

Liew V.K.S. (2004) What lag length selection criteria should be employ? Economic Bulletin. http://myais.fsktm.um.edu.my/4036/1/EBLag_Selection_04.pdf. Data access on 18 April. 2012. Access on August 18, 2012.

Pattillo, C., Poirson, H. \& Luca, R. (2002) External debt and Growth. IMF working paper. 39(02).

Sinha P., Arora V., \& Bansal V. (2011) Determinant of public debt for middle income and high income group countries using panal data regression. Munich personal RePEc Archive. http://mpra.ub.uni-muenchen.de/32079/1/MPRA_paper_32079.pdf. Data access on 27 April 2012.

Schclarek, A., (2004) Debt and Economic Growth in Developing Industrial Countries. mimeo.

20. World fact book (2013). The economy of Greece. http://www.theodora.com/wfbcurrent/greece/greece_economy. html.

Yue, Z.V. (2010) Sovereign default and debt renegotiation. Journal of international Economics, pp.176-189.

\section{Appendix}

Appendix 1: Stability test results

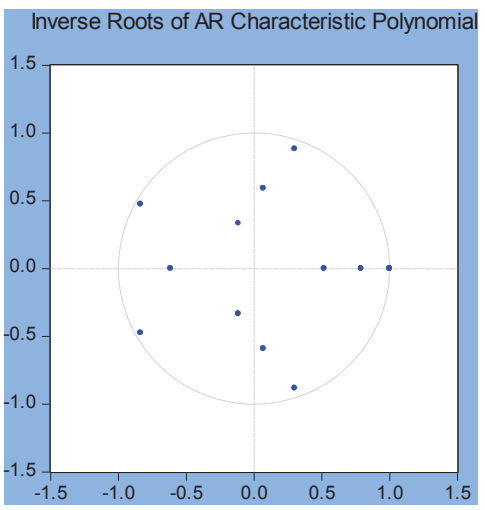

Appendix 2: The summary of diagnostics and stability tests results of our regression

\begin{tabular}{|l|l|c|c|l|}
\hline \multicolumn{1}{|c|}{ Test } & \multicolumn{1}{c|}{ Null Hypothesis } & Test statisitcs & P- value & \multicolumn{1}{c|}{ Conclusion } \\
\hline Autocorrelation LM test & No serial correlation & At lag 2, LM stat=19.670 & 0.764 & There is no serial correlation \\
\hline White without cross terms & No heteroskedasticity & Chi square $=343.013$ & 0.230 & There is no heteroskedasticity \\
\hline Jarque Bera & $\begin{array}{l}\text { Residuals are normally } \\
\text { distributed }\end{array}$ & JB $=3.754$ & 0.958 & $\begin{array}{l}\text { The model is normally } \\
\text { distributed }\end{array}$ \\
\hline
\end{tabular}

